Erik Damgaard

\title{
Ændringer i den parlamentariske kultur
}

\begin{abstract}
Artiklen er et første forsøg på at beskrive nogle væsentlige elementer af den parlamentariske kultur i Danmark. På basis af en bred definition af parlamentarisk kultur omtales forst en række generelle og forholdsvis stabile træk, sammenfattet under betegnelserne wlivsformen", "værdigheden * og wuformelle normer*. Derefter behandles vigtige ændringer i de sidste ảrtier under overskrifterne "professionalisering * og weksperimenteren $\propto$, hvoraf sidstnævnte potentielt repræsenterer en radikal forandring af den parlamentariske kultur i Danmark.
\end{abstract}

\section{Indledning}

Et lands parlamentariske kultur er en del af dets politiske elites kultur. Politisk kultur er imidlertid ikke et entydigt begreb (Pye, 1968). I en af de hyppigst benyttede definitioner af politisk kultur tales om nattitudes toward the political system and its various parts, and attitudes toward the role of the self in the system " (Almond \& Verba, 1965: 12). Almond \& Verba er optaget af den politiske kultur på masseniveauet, dvs. de holdninger og opfattelser, som er udbredte i den almindelige befolkning. Men en beslægtet definition er også benyttet på eliteniveauet (for eksempel Putnam, 1971).

Det er dog et spørgsmål, om begrebet politisk kultur ikke bør omfatte andet og mere end holdninger og opfattelser. Jørgen Goul Andersen har sảledes foreslảet, at det også bør inkludere handlinger i relation til det politiske system (Andersen, 1984). Et tilsvarende synspunkt er lagt til grund i det følgende ud fra den betragtning, at holdninger uden handlingsmæssige konsekvenser er uden større interesse.

Om parlamenter og parlamentarikere er skrevet et utal af bøger, i hvert fald uden for Skandinavien. Ingen af dem synes dog at have anvendt parlamentarisk kultur som centralt begreb i analysen. Nærmest kommer nok et par kapitler i U.S. Senators and Their World (Matthews, 1960) og nogle artikler af Ralph K. Huitt (optrykt i Huitt \& Peabody, 1969). I denne artikel vil jeg søge at skitsere træk af den danske parlamentariske kultur og ændringer i samme på basis af tidligere foretagne undersøgelser. I bredeste forstand er parlamentarisk kultur en særlig livsform bestående af et sæt politiske holdninger, opfattelser og aktiviteter. I en lidt snævrere forstand kan tales om parlamentarisk kultur i betydningen holdninger, opfattelser og handlinger, der knytter sig direkte til folketingsarbejdet, herunder Folketingets forhold til regeringen.

En parlamentarisk kultur opstår og ændres i et samspil mellem dels politikere indbyrdes, dels politikere og deres omgivelser. Til omgivelserne hører ikke blot andre politiske institutioner, organisationer, pressen, vælgerne osv., men ogsả de 
Erik Damgaard

\title{
Ændringer i den parlamentariske kultur
}

\begin{abstract}
Artiklen er et første forsøg på at beskrive nogle væsentlige elementer af den parlamentariske kultur i Danmark. På basis af en bred definition af parlamentarisk kultur omtales forst en række generelle og forholdsvis stabile træk, sammenfattet under betegnelserne wlivsformen", "værdigheden * og wuformelle normer*. Derefter behandles vigtige ændringer i de sidste ảrtier under overskrifterne "professionalisering * og weksperimenteren $\propto$, hvoraf sidstnævnte potentielt repræsenterer en radikal forandring af den parlamentariske kultur i Danmark.
\end{abstract}

\section{Indledning}

Et lands parlamentariske kultur er en del af dets politiske elites kultur. Politisk kultur er imidlertid ikke et entydigt begreb (Pye, 1968). I en af de hyppigst benyttede definitioner af politisk kultur tales om nattitudes toward the political system and its various parts, and attitudes toward the role of the self in the system " (Almond \& Verba, 1965: 12). Almond \& Verba er optaget af den politiske kultur på masseniveauet, dvs. de holdninger og opfattelser, som er udbredte i den almindelige befolkning. Men en beslægtet definition er også benyttet på eliteniveauet (for eksempel Putnam, 1971).

Det er dog et spørgsmål, om begrebet politisk kultur ikke bør omfatte andet og mere end holdninger og opfattelser. Jørgen Goul Andersen har sảledes foreslảet, at det også bør inkludere handlinger i relation til det politiske system (Andersen, 1984). Et tilsvarende synspunkt er lagt til grund i det følgende ud fra den betragtning, at holdninger uden handlingsmæssige konsekvenser er uden større interesse.

Om parlamenter og parlamentarikere er skrevet et utal af bøger, i hvert fald uden for Skandinavien. Ingen af dem synes dog at have anvendt parlamentarisk kultur som centralt begreb i analysen. Nærmest kommer nok et par kapitler i U.S. Senators and Their World (Matthews, 1960) og nogle artikler af Ralph K. Huitt (optrykt i Huitt \& Peabody, 1969). I denne artikel vil jeg søge at skitsere træk af den danske parlamentariske kultur og ændringer i samme på basis af tidligere foretagne undersøgelser. I bredeste forstand er parlamentarisk kultur en særlig livsform bestående af et sæt politiske holdninger, opfattelser og aktiviteter. I en lidt snævrere forstand kan tales om parlamentarisk kultur i betydningen holdninger, opfattelser og handlinger, der knytter sig direkte til folketingsarbejdet, herunder Folketingets forhold til regeringen.

En parlamentarisk kultur opstår og ændres i et samspil mellem dels politikere indbyrdes, dels politikere og deres omgivelser. Til omgivelserne hører ikke blot andre politiske institutioner, organisationer, pressen, vælgerne osv., men ogsả de 
rent fysiske rammer for parlamentarisk virksomhed. Den parlamentariske kultur tilegnes gennem en parlamentarisk socialiseringsproces (Bell \& Price, 1975; Badura \& Reese, 1976), dvs. en læreproces hvorigennem nyvalgte stifter bekendtskab med og tilegner sig de for parlamentarikere gældende vilkår, rådende normer og accepterede adfærdsformer i stort og småt.

I de næst følgende afsnit skitseres den parlamentariske kultur generelt: livsformen, den parlamentariske værdighed og nogle uformelle normer. Derefter fokuseres specielt på udviklingen de sidste 10-15 år, der på vigtige punkter har ændret den parlamentariske kultur i Danmark. Spørgsmålet er her, om disse ændringer har mere permanent karakter.

\section{Livsformen}

På basis af flere forskelligartede undersøgelser af folketingsmedlemmers aktiviteter og opfattelser (Damgaard, 1977; Damgaard m.fl., 1979; Damgaard, 1982; se Skard, 1981, for en norsk politikers og politologs erfaringer) kan fastslås, at folketingsarbejdet $\mathrm{i}$ bred forstand er en særlig livsform. Det lægger beslag på mere tid end et sædvanligt fuldtidsjob. Det griber så dybt ind i medlemmernes tilværelse, at næsten alt andet må indrettes derefter. Medlemmernes privat- eller hjemmetilværelse er stærkt beskåret, normalt erhvervsarbejde opgivet eller kraftigt reduceret og megen rejseaktivitet nødvendig af hensyn til arbejdet på Christiansborg og møder andre steder. Den samlede arbejdsbyrde er meget stor - også i sammenligning med en gymnasielærers eller professors. Arbejdsopgaverne er ikke indbyrdes velafgrænsede eller kronologisk ordnede. Arbejdet er mangeartet, skiftende og omfatter ofte flere ting på én gang. Evnen til at følge med i flere ting på én gang er nærmest en overlevelsesbetingelse, og aktiviteterne har ofte et hektisk præg. En udenforstående bliver overrasket over det omfang, hvori medlemmerne er optaget af aktiviteter uden for lovgivningsarbejdet i snæver forstand. Medlemmerne er ikke isolerede på Christiansborg. De modtager mange henvendelser udefra, som kræver stillingtagen. De deltager i mange møder og har kontakter til mange individer og grupper i samfundet. En stor andel af medlemmerne lægger specielt vægt på en tæt kontakt til valgkredsen. Som K. Helveg Petersen har udtrykt sig:

\footnotetext{
"Hvis man narmere folger en folketingsmands arbejde, vil man se, hvorledes han pisker af sted fra opgave til opgave: mader ude omkring $i$ landet, udvalgsmøder, besvarelse af breve fra vælgerne, udarbejdelse af artikler, gennemgang af kommissions- og udvalgsbetænkninger, tidsskrifter, aviser (lokale og landsdækkende) osv. Han er altid på farten, aldrig i ro. Når som helst kan han blive kaldt til telefonen for at tage stilling til et eller andet (nu endda ved hjælp af et afskyeligt elektronisk kaldeapparat, man bærer pả sig). Den sekretærhjælp, han har, er yderst begrænset, og endnu er det kun et mindretal af folketingets medlemmer, der har deres eget (beskedne) arbejdsværelse. " (Petersen, 1974)
}

Selvom der, som omtalt nedenfor, er sket vigtige ændringer de senere år, er folketingsarbejdet ikke specielt vellønnet og bistanden ikke just overvældende. Man kan derfor spørge, hvorfor nogen i det hele taget vælger en sảdan livsform. Gunnar Fog-Petersen skrev for 50 år siden: 
"Den Rigsdagsmand, som vil stræbe frem mod ledende Stillinger i Partiet, maa kunne give Afkald pả alt andet. Han maa leve og aande i Politik. De fleste som er blevet indfanget af det politiske Arbejde, elsker dette spændende og afvekslende stærkt krævende Liv. Slaas de ud deraf midt i Arbejdet, er det for mange skæbnesvangert ... Selv om det for de fleste er en daarlig okonomisk Lod at tiene det offentlige, vil dog den, der engang er blevet grebet af dets Fortryllelse, nodigst af alt forlade det. (Fog-Petersen, 1938: 13)

Den lige så kyndige iagttager Svend Thorsen skrev tilsvarende ti år senere:

„Rigsdagen og Gerningen dér bliver Parlamentarikerens halve Liv, ofte mere. Det er den gamle Erfaring: Teaterkulisser, Redaktionskontorer og Parlamenter vedbliver at udøve en Dragning paa den, som en Gang har været indenfor. Faa eller ingen kan frigøre sig for Tiltrækningen. * (Thorsen, 1949: 165)

Donald Matthews fandt, at amerikanske senatorers arbejdspres krævede en næsten overmenneskelig energi. Senatorernes egne udtalelser om hvervet var da også præget af ambivalens. Som en af dem sagde: "I don't know why anyone would want this job - Don't quote me on that, I'm running for re-election!' (Matthews, 1960: 91).

I danske folketingsmedlemmers tilværelse har Partiet en meget central rolle. Kandidater opstilles, vælges og genvælges i partiregi. For medlemmer af $i$ hvert fald de gamle partier gælder typisk, at de er vokset op med partiet, om end ingen regel er uden undtagelser. Medlemmerne føler sig først og fremmest som repræsentanter for partiets politik, selvom der i enkelte spørgsmål og lokale anliggender undertiden kan forekomme afvigelser fra partilinien (jfr. Pedersen, 1967; Svensson, 1982). Partigrupperne i Folketinget har særdeles stor betydning i det daglige arbejde. Gruppemøderne er utvivlsomt de mest velbesøgte af alle møder i Folketinget (Damgaard m.fl., 1979: 51, 100-103). Gruppemødet er et forum for fastlæggelse af partiets konkrete standpunkter og en ramme om den nødvendige specialisering og koordinering af medlemmernes aktiviteter. Det er ligeledes et vigtigt led i det enkelte medlems informationsnetværk ikke mindst i spørgsmảl, der ligger uden for vedkommendes egne specialiseringsomrảer (Damgaard, 1982: 67-72).

\section{Værdigheden}

Parlamenters bygningsmæssige rammer og fysiske indretning tilsigter almindeligvis at udsträle værdighed og at indgyde respekt (Loewenberg \& Patterson, 1979: 140-142). I.C. Christensen skal endog have ment, at tingsalen burde behandles "med samme Respekt, som den, hvormed man gaar over Kirkens Tærskel og under dens Hvælvinger « (Fog-Petersen, 1938: 9). Rigtigt er det naturligvis, at Folketinget er ukrænkeligt. At antaste dets sikkerhed eller frihed er højforræderi (Grundloven, \$34). Trods visse stramninger i de senere àr er Folketinget dog stadig et af de i bogstavelig forstand mest ảbne parlamenter i verden.

Den i forretningsordenen gennemregulerede forhandlingsform er den kultiverede diskussions form. Formanden leder forhandlingerne og "sørger for opretholdelse af god orden og en værdig forhandlingsform" (Forretningsorden, \$4). Folketinget er mảske knap sả selvdisciplineret som det norske Storting, der er 
kaldt "den verdigste nasjonalforsamling i sin daglige praksis" (Blichner \& Olsen, 1986: 84), og værdigheden er mindre fremtrædende end før i tiden. Tiltaleformens ændring viser lidt om udviklingen.

"Det ærede medlem" (oprindelig med fortsættelsen: "fra ... Amts ... Valgkreds «) og "den højtærede minister « var former, der benyttedes fra første færd og helt op til midten af 1960erne, da de afløses af de mere flade udtryk "hr. ", "fru " og "ministeren". Formen "det ærede medlem « må stadig anvendes, men det er fortsat forbudt at tiltale nogen direkte under forhandlingerne, hvad den parlamentariske sprogfornyer Mogens Glistrup måtte sande få sekunder efter, at han for første gang fik ordet i Folketinget.

Værdigheden afspejles også i, hvad der anses for passende påklædning i Folketinget. Det er ikke så mange år siden, mandlige medlemmer fik lov at smide jakken, når klimaet blev for utảleligt i folketingssalen. Siden er formerne blevet mere afslappede, om end det stadig anses for upassende, at mandlige medlemmer møder op i shorts. Det er velkendt, at klædedragten kan anvendes til symbolsk at markere visse holdninger. For mandlige folketingsmedlemmer er jakke og slips nok stadig den foretrukne fremtrædelsesform, men en empirisk analyse af medlemmernes pảklædning (mandlig såvel som kvindelig) blandt for eksempel konservative og SFere, vil utvivlsomt påvise eksistensen af parlamentariske subkulturer i så henseende.

Den parlamentariske kultur præges dog under alle omstændigheder af en særlig form for orden og værdighed, selvom parlamentet er en ramme om konflikter og stridigheder mellem forskellige synspunkter og interesser. Den særlige form for formel høflighed er ikke betydningsløs, idet den virker fremmende for det samarbejde, der også kræves af konkurrenter.

\section{Uformelle normer}

I et kapitel med titlen "The Folkways of the Senate " søgte Matthews (1960) at beskrive det amerikanske senat som socialt system ved at fremhæve dets uformelle normer eller spilleregler. Den første regel, man må tilegne sig, er "læretid" (apprenticeship). Det nyvalgte medlem skal ikke forvente sig for meget. Han må affinde sig med udvalgsposter, andre ikke vil have, skal kunne holde sin mund og i øvrigt vise ældre medlemmer respekt. Således var det også tidligere i Danmark: "I Fredericiagade gik der som Regel adskillige Aar, inden en nyvalgt blev betroet at være Ordfører " (Thorsen, 1949: 44). Svend Thorsen tilføjede, at der i vor tid (dvs. 1949) tages langt større hensyn til de unge end tidligere. Der kan dog stadig findes eksempler på, at nyvalgte føler sig tilsidesat:

"Det nye medlem skal ikke regne med automatisk at blive placeret $\mathrm{i}$ de udvalg, hvor hans interesser ligger, og hvor hans viden muligvis kan have en vis gavn. Andre ... sad der i forvejen og vil naturligt nok ikke vige pladsen. Og sảledes er det, sả vidt jeg kan forstả, i alle partier.* (Budtz, 1974)

I en analyse af den svenske rigsdag konstaterer Magnus Isberg stilfærdigt: "... det är uppenbart att nyvalda ledamöter i många fall måste sitta i utskott för vilka de varken har intresse eller kunskaper (Isberg, 1984: 26). 
Alligevel er der ikke tvivl om, at den parlamentariske læretid i gammeldags forstand er passé. Allerede for jordskredsvalget i 1973 var der sket markante ændringer. J.O. Krag skrev i sig dagbog for 25 . november 1971:

„Fra kl. 16-18 havde vi markedsdebat i den socialdemokratiske gruppe ... Jeg spekulerede pá, om dansk politik ikke er ved at skifte struktur. Den ene efter den anden af gruppens nye medlemmer rejste sig og gav deres mening til kende - i øvrigt i en positiv og kammeratig and. Noget tilsvarende - at »de nye * overhovedet tog ordet - ville have været utænkeligt for blot 10 ár siden. Og at de havde ytret sig for andre synspunkter $i$ en sả central vigtig sag, som EF-sagen er, end svarende til de meninger, ledelsen har, ville vare blevet opfattet som optræk til en katastrofe. * (Krag, 1973: 91)

Blandt de i september 1971 nyvalgte socialdemokrater var Svend Auken, Ritt Bjeregaard, Helle Degn, Karl Hjortnæs, Inge Fischer Møller og Birte Weiss.

En anden af Matthews fremhævet norm kræver, at sagligt lovgivningsarbejde går forud for forsøg på at komme i offentlighedens rampelys for at score billige points. Da politikere er forskellige, kan man opleve, at de af kollegerne mest respekterede senatorer er næsten ukendte af offentligheden og omvendt, at "kendte " politikere ikke er særligt respekterede af kollegerne. Scriøst og grundigt arbejde med store og små problemer aftvinger formentlig også respekt blandt danske politikere. De fleste kan sikkert, helt uanset partiskel, vurdere de øvrige medlemmer ved hjælp af et sådant kriterium. Massemediernes udvikling, herunder specielt TVs, har dog utvivlsomt gjort det mere attraktivt for medlemmerne at søge publicity, hvilket ikke behøver at være pả bekostning af sagligt arbejde. Partigrupperne og deres ordførere i forskellige spørgsmål må jo, i modsætning til amerikanske senatorer, konkurrere med hinanden. Desuden må fremhæves, at selvom politikere nok ønsker at udnytte pressens kommunikationskanaler, har de også en betydelig skepsis over for journalister (Damgaard, 1982: 55-60; Damgaard m.fl., 1979, kap. 7).

En tredie norm har imidlertid næsten universel udbredelse: nødvendigheden af specialisering. Den gælder for alle parlamenter med reel indflydelse. Udvalgsreformen i Folketinget 1972/73 skabte de nuværende rammer for specialiseringen (Damgaard, 1977; Hansen, 1985). En spørgeskemaundersøgelse viste, at medlemmerne først og fremmest anfører en personlig interesse som begrundelse for medlemskab af givne udvalg (Damgaard, 1982). Den bekræfter derved indirekte, at "læretidsnormen " ikke længere har den store betydning.

Matthews nævner endelig som vigtige uformelle normer "gensidighed " reciprocity) og vinstitutionel patriotisme". I det individualistiske amerikanske senat er gensidigheden først og fremmest et spørgsmảl om udveksling af tjenester eller stemmer. I Danmark er problematikken mere kompliceret. For det første rummer den et parti-internt aspekt. En folketingsgruppe forventes at optræde enig og samlet udadtil, ellers vil den hurtigt fä problemer. Set fra det enkelte medlems synsvinkel kræves loyalitet over for gruppen. Svigtende loyalitet kan medføre sanktioner, for eksempel i form af fratagelse af ordførerskaber og udvalgsmedlemskaber. For det andet vedrører problematikken forholdet mellem partigrupper. Trods forekomsten af stærke partipolitiske modsætningsforhold og undertiden 
knivskarpe afstemningsudfald præges Danmark grundlæggende af en forhandlings- og kompromiskultur. Den indebærer aftaler og forlig mellem to eller flere partier. Normen siger nu som for, at aftaler skal holdes af de deltagende parter. I denne sammenhæng kan også nævnes den uformelle norm om, at man ikke offentligt refererer, hvad andre har udtalt i lukkede møder eller private samtaler.

Indslag af winstitutionel patriotisme « kan også iagttages i Folketinget. Ministre må for eksempel ikke komme for sent til møder, hvori deres deltagelse er påkrævet. De skal møde op og besvare de spørgsmål, der stilles under udvalgenes samråd med ministre. Blandt udvalgene har finansudvalget og markedsudvalget en særlig stærk stilling som repræsentant for Folketinget over for regeringen, idet finansudvalget afgør bevillingssager og markedsudvalget giver regeringen mandat til forhandlingerne i EFs ministerråd. Som yderligere et eksempel på institutionel patriotisme kan nævnes, at en minister, som masseproducerede spørgsmål, der ønskedes stillet af folketingsmedlemmer med henblik på afgivelse af på forhånd udarbejdede svar, mødtes med skarpe reaktioner. Generelt kan måske siges, at især Folketingets formand og præsidium vil være blandt de mest "patriotiske" på tingets vegne. Det er muligt, at patriotismen var større i gamle dage, men der er fortsat grænser, som ikke må overskrides.

\section{En ny parlamentarisk kultur?}

Hvad der hidtil er sagt om parlamentarisk kultur, er ikke specielt møntet på de senere år, hvor der imidlertid er sket så meget, at der er god grund til at stille spørgsmålet, om en ny parlamentarisk kultur er opstået. Hvis man med to ord skulle karakterisere de mange nye tendenser, måtte det være "professionalisering “ og »eksperimenteren «.

Professionaliseringen angår Folketingets udvikling og medlemmernes ændrede situation, medens eksperimenteren præger forholdet mellem opposition og regering.

\section{Professionalisering}

Begrebet professionalisering har mange aspekter også i en parlamentarisk sammenhæng. Væsentlige er tendenserne til specialisering og den omstændighed, at det politiske arbejde er blevet et fuldtidsjob.

Folketinget var oprindelig en forsamling af repræsentanter valgt ved flertalsvalg $\mathrm{i}$ enkeltmandskredse af et mindretal af den voksne befolkning. At være folketingsmand betragtedes som et tillidshverv med begrænset arbejdsbyrde. Det ret beskedne antal sager kunne diskuteres uden taletidsbegrænsninger. Som kompensation for indsatsen modtog medlemmerne beskedne daglige diæter i mødeperioden, der var tilpasset arbejdsrytmen i landbrugssamfundet Danmark. Udvalgsarbejdet var af begrænset omfang, medlemmerne havde ikke personlig hjælp til rảdighed, og Folketingets stab bestod af nogle fả personer.

I dag vælges medlemmerne af næsten hele den voksne befolkning på lister opstillet af organiserede politiske partier. Medlemskabet er fortsat et tillidshverv, men arbejdsbyrden er som nævnt vokset voldsomt. I 1920 afløstes diæterne af et årligt vederlag, og fra 1954 udbetaltes lønnen som et skattepligtigt grundbeløb, 
der er ens for alle, og et skattefrit omkostningstillæg, der varierer efter bopælens afstand fra København. Efter årtiers diskussion forhøjedes grundvederlaget $\mathrm{i}$ 1986. Det svarer nu nogenlunde til den løn, man fär som lektor på et universitet.

Endnu i 1965 kunne Poul Meyer skrive: "Der findes i den vestlige verden kun få folkerepræsentationer, hvor medlemmerne har så beskedne faciliteter til rådighed som det danske folketing "(Meyer, 1965: 50). Derefter tog udviklingen imidlertid fart: i løbet af de næste godt femten år ansattes flere embedsmænd i Folketingets forskellige kontorer; der indførtes i flere etaper økonomisk støtte til partigrupperne; medlemmerne fik hver især eget kontor og adgang til at trække på en personlig sekretærhjælp, der nu svarer til $1 / 2$ HK-stilling. Hertil kommer, at der fra 1986 er afsat betydelige midler til forberedelse og begyndende installation af et omfattende edb-system, der efterhånden skal kunne benyttes til en lang række arbejdsopgaver (tekstbehandling, arkivering, kommunikation, adgang til interne og eksterne databaser, etc.).

I løbet af 1960erne begyndte man også at erkende uhensigtsmæssigheden af at nedsætte et "særligt udvalg " til behandling af et enkelt eller eventuelt flere sammenhængende forslag. Man indførte derfor forsøgsvist nogle stående, specialiserede udvalg på visse områder og 11972 gennemfortes en radikal omlægning af udvalgssystemet, således at arbejdet nu helt overvejende sker i godt tyve stående, specialiserede udvalg. Det nye udvalgssystem har muliggjort behandling af et langt større antal sager, det har givet medlemmerne forbedrede kontrolmuligheder i forhold til regeringen (deraf diskussionen om "specialisterne « i Folketinget, der "blander sig " i administrative anliggender), og det har skabt permanente fora for henvendelser fra offentligheden i store og smả spørgsmål. Holger Hansen konkluderer, at udvalgene er blevet "magtfaktorer ", der har "flyttet grænsepæle mellem den lovgivende og udøvende magt " (Hansen, 1985: 210, 190).

De nævnte ændringer repræsenterer fortsatte skridt i retning bort fra tidligere tiders idé om et parlament sammensat af deltids, all-round orienterede politikere, der klarer sig ved hjælp af et beskedent vederlag og egne personlige ressourcer, over mod en mere nutidig forestilling om et parlament sammensat af fuldtidspolitikere med behov for dels en betydelig grad af specialisering, dels forskellige former for bistand og faciliteter. Den parlamentariske kultur er kort sagt blevet mere professionaliseret i de sidste årtier.

Det "nye " Folketing er på mange måder mere aktivt og kritisk end det "gamle«. Talrige indikatorer for aktivitetsniveauet i Folketingets sal og udvalg vidner om en markant aktivitetsstigning de sidste 10-15 år (Folketingsårbog 1985-86). Aktivitetsstigningen har flere årsager. For det første, at Folketinget ved valget $\mathrm{i}$ december 1973 tilførtes et antal nye partier og en dermed sammenhængende større spredning i politiske synspunkter. For det andet, at medlemmer og partigrupper i stigende grad har benyttet sig af de eksisterende initiativmuligheder (lovforslag, beslutningsforslag, forespørgsler, spørgsmål i sal og via udvalg). Endelig hører med til forklaringen, at de forbedrede arbejdsbetingelser og systemet af stående, specialiserede udvalg har understøttet et højere aktivitetsniveau. Trods reduktioner af taletiderne for behandling af forslag, redegørelser og forespørgsler har der aldrig været talt sả meget i Folketinget, som i det seneste tiảr. 


\section{Eksperimenteren}

De formelle og uformelle normer, der regulerer forholdet mellem partier i opposition og regering, er selvsagt en central del af den parlamentariske kultur. Det parlamentariske princip (dvs. kravet om, at en regering skal gå af eller udskrive valg, dersom den mødes af et mistillidsvotum i Folketinget) og den praksis, der havde udviklet sig vedrørende regeringsdannelser, er uændrede, men meget blev iøvrigt pảvirket af partisystemets fragmentering i 1973. Valgresultaterne i tiden derefter medførte på den ene side mindretalsregeringer på mere usikre vilkår, end man tidligere havde kendt, og på den anden side forskellige forsøg på tilpasning til samme usikre vilkảr. Man har sả at sige eksperimenteret med sædvanlig parlamentarisk praksis i forholdet mellem opposition og regering for at komme ud over de vanskeligheder, partisystemets fragmentering medførte.

Den utraditionelle regeringskoalition mellem Socialdemokratiet og Venstre 1978-79 var et sådant forsøg på at bryde regeringsustabiliteten. Den afveg fra de kendte mønstre for partisamarbejde pả regeringsniveau. Den afveg imidlertid også fra sædvanlig praksis ved, at regeringspartierne ikke kunne enes ret længe og derfor opløste samarbejdet.

Med og under firkløverregeringen (1982- ) er der foretaget flere eksperimenter med velkendt parlamentarisk praksis. Regeringen består af ikke færre end fire partier, men er alligevel en mindretalsregering. Efter en del usikkerhed i det første år opnåede regeringen efter valget i januar 1984 et fast grundlag for den økonomiske politik i kraft af et samarbejde med de radikale. Da de radikale imidlertid også indgik i andre flertalsdannelser, fik regeringen problemer på andre områder, jfr. nedenfor.

Forinden bør dog nævnes, at valget i 1984 blev udskrevet, fordi ikke blot Fremskridtspartiet, der hidtil havde støttet regeringen, men også Socialdemokratiet stemte imod regeringens finanslovforslag. Den normale parksis er ellers, at et "ansvarligt " parti (som for eksempel Socialdemokratiet) stemmer for finanslovforslaget uanset dets forhold til den siddende regering, og selvom det måtte være uenigt i væsentlige dele af dens indhold. Det har imidlertid også været accepteret, at selv et "ansvarligt « parti kan søge at fælde en regering under afstemning om finanslovforslaget, hvis regeringen har søgt flertal til anden siden uden at have flertallet i orden. Dette var, hvad Socialdemokratiet gjorde under afstemningen, idet partiet dog også henviste til, at det ikke havde haft rimelig indflydelse på finanslovforslagets indhold, hvilken sidste begrundelse ifølge Erik Rasmussen (1985) strider mod hævdvunden praksis for wansvarlige " partiers adfærd.

Mindretalsregeringer har altid i en vis udstrækning mảttet bøje sig for andre partiers synspunkter for at fa lovforslag gennemført. Men ingen regering har fundet sig i så mange nederlag som firkløverregeringen. Det normale har været, at en regering ikke accepterer et afstemningsnederlag i et væsentligt spørgsmål: "Man kan derfor sige, at enhver afstemning er en tillidsafstemning (Worre, 1982: 102). Denne beskrivelse er ikke gældende for firkløverregeringen, med mindre man da vil indskrænke "væsentlige" spørsmål til kun at omfatte centrale $ø$ konomiske lovforslag. Et meget stort antal lovforslag, beslutningsforslag og motiverede dagsordener er vedtaget af det "alternative flertal", der ikke omfatter re- 
geringen, men radikale, socialdemokrater og venstrefløjen. Dette flertal har truffet afgørelser uden om regeringen på en række områder, herunder udenrigs- og sikkerhedspolitik, energipolitik, miljøpolitik, kulturpolitik og retspolitik, og må betegnes som en bemærkelsesværdig nydannelse i dansk parlamentarisme. Regeringens rolle har undertiden været indskrænket til modvilligt at udarbejde de forslag, der ønskedes gennemført af det alternative flertal.

For at bevare regeringsmagten og muligheden for at føre den ønskede økonomiske politik har firkløverregeringen altså affundet sig med et stort antal nederlag. Det er der intet ulovligt $\mathrm{i}$, men det repræsenterer et brud på hidtidig parlamentarisk praksis i Danmark.

Regeringen affandt sig dog ikke med alle nederlag (selv bortset fra den netop omtalte finanslovsafstemning), idet den ikke ville acceptere det alternative flertals nej til ratifikation af EF-pakken $i$ januar 1986. Der var unægtelig tale om et væsentligt spørgsmảl, og da en genforhandling af traktaten ikke var en realistisk udvej, havde regeringen tilsyneladende to muligheder: at udskrive valg eller at træde tilbage. Meget overraskende valgte den imidlertid at foreslå en tredje udvej i form af en rådgivende folkeafstemning, som accepteredes af både socialdemokrater og radikale. Folkeafstemninger er ingenlunde ukendte i Danmark. Det interessante $\mathrm{i}$ forbindelse med afstemningen om EF-pakken er i denne sammenhæng, at en regering, der blev nedstemt i Folketinget i en væsentlig sag, kunne appellere direkte til befolkningen for at omgøre folketingsflertallets beslutning, og ovenikøbet have held med appellen. Også her er der tale om en bemærkelsesværdig ændring af parlamentarisk praksis.

\section{Kontinuitet og forandring}

Mange elementer i den parlamentariske kultur er stabile eller forandres kun meget langsomt $\mathrm{i}$ tidens løb. De bidrager derved til opretholdelse af en for det parlamentariske system nødvendig grad af orden og forudsigelighed. Dette gælder i vid udstrækning for, hvad der er omtalt under overskrifterne livsformen, værdigheden og uformelle normer. Andre elementer kan ændres betydeligt over en forholdsvis kort årrække, som det ses i forbindelse med de sidste årtiers tiltagende professionalisering. Denne professionalisering indebærer ændringer af tilvante forestillinger og arbejdsformer. Den kan ses som en tilpasning til ændringer i omgivelser og arbejdsbetingelser for at bevare de folkevalgtes indflydelse over for andre aktører, herunder bureaukrater, eksperter, organisationer og institutioner. Endelig findes ændringer, som udspringer af mere kortsigtede og taktiske overvejelser. De kan løse øjeblikkelige problemer, men mảske ogsả skabe nye på længere sigt. Det er nok rimeligt hertil at henføre nogle af de "eksperimenter", der er foretaget i de seneste år. Om disse eksperimenter bliver til permanente ændringer af den parlamentariske kultur - som professionaliseringen er blevet det - kan man i dag kun gisne om. Hvis det viser sig at være tilfældet, er der tale om en ganske radikal forandring af den parlamentariske kultur i Danmark. 


\section{Litteratur}

Almond, Gabriel A. \& Verba, Sidney (1965). The Civic Culture, Boston: Little, Brown.

Andersen, Jørgen Goul (1984). »Aspekter af den politiske kultur i Danmark efter 1970«, pp. 17-49 i Erik Damgaard m.fl., Dansk demokrati under forandring, Kobenhavn: Schultz.

Badura, Bernhard \& Reese, Jürgen (1976). Jungparlamentarier in Bonn - ihre Sozialisation im Deutschen Bundestag, Stuttgart: Friedrich Frommann.

Bell, Charles G. \& Price, Charles M. (1975). The First Term. A Study of Legislative Socialization, Beverly Hills \& London: Sage.

Blichner, Lars Chr. \& Olsen, Johan P. (1986). Spersmàl $i$ Stortinget, Oslo: Universitetsforlaget.

Budtz, Lasse (1974). Kend din plads i tinget!«, kronik i Aarhuus Stiftstidende, 18. marts.

Damgaard, Erik (1982). Partigrupper, representation og styring, København: Schultz.

Damgaard, Erik (1977). Folketinget under forandring, København: Samfundsvidenskabeligt Forlag.

Damgaard, Erik, m.fl. (1979). Folketingsmedlemmer pả arbejde, Århus: Forlaget Politica.

Fog-Petersen, Gunnar (1928). Vor Regering og Rigsdag, København: Gyldendal.

Hansen, Holger (1985). Folketingets staende udvalg, København: Jurist- og Økonomforbundets Forlag.

Huitt, Ralph \& Peabody, Robert L. (1969). Congress: Two Decades of Analysis, New York: Harper \& Row.

Isberg, Magnus (1984). Riksdagens Roll under 1970-talet, Stockholm: Akademilitteratur.

Krag, Jens Otto (1973). Dagbog 1971-1972, København: Gyldendal.

Loewenberg, Gerhard \& Patterson, Samuel P. (1979). Comparing Legislatures, Boston: Little, Brown.

Matthews, Donald R. (1960). U.S. Senators and Their World, Chapel Hill: University of North Carolina Press.

Meyer, Poul (1965). Politiske Partier, København: Nyt Nordisk Forlag.

Pedersen, Mogens N. (1967). „Consensus and Conflict in the Danish Folketing 1945-65«, pp. 143-166 i Scandinavian Political Studies, vol. 2.

Petersen, K. Helveg (1974). »Magten flyttes fra Folketinget $\alpha$, kronik i Politiken, 12. november.

Putnam, Robert D. (1971). »Studying Elite Political Culture: The Case of 'Ideology' «, The American Political Science Review, vol. LXV, no. 3, pp. 651-681.

Pye, Lucian W. (1968). "Political Culture «, pp. 218-225 i International Encyclopedia of the Social Sciences, vol. 12.

Rasmussen, Erik (1985). „Finanslovsforkastelse i dansk parlamentarisme: Normer og konsekvenser «, Historie, Jyske Samlinger, Ny række 16,1, pp. 56-118.

Skard, Torild (1981). Hverdag pả Løvebakken, Oslo: Gyldendal Norsk Forlag.

Svensson, Palle (1982). "Party Cohesion in the Danish Parliament during the 1970s", Scandinavian Political Studies, vol. 5, pp. 17-42.

Thorsen, Svend (1949). Danmarks Rigsdag, København: Forlaget Fremad.

Worre, Torben (1982). Det politiske system i Danmark, København: Akademisk Forlag. 